\title{
Article \\ The Effect of Frequency of Fresh Pasture Allocation on the Feeding Behaviour of High Production Dairy Cows
}

\author{
Jessica G. Pollock ${ }^{1,2, *(\mathbb{D}, \text { Alan W. Gordon }}{ }^{3}$, Kathryn M. Huson ${ }^{2}$ and Deborah A. McConnell ${ }^{2}$ \\ 1 School of Biological Sciences, Queens University Belfast, Belfast BT9 7BL, UK \\ 2 Agri-Food and Biosciences Institute, Large Park, Hillborough BT26 6DR, UK; \\ kathryn.huson@afbini.gov.uk (K.M.H.); deborah.mcconnell@afbini.gov.uk (D.A.M.) \\ 3 Agri-Food and Biosciences Institute, 18a Newforge Lane, Belfast BT9 5PX, UK; alan.gordon@afbini.gov.uk \\ * Correspondence: jpollock16@qub.ac.uk
}

check for updates

Citation: Pollock, J.G.; Gordon, A.W.; Huson, K.M.; McConnell, D.A. The Effect of Frequency of Fresh Pasture Allocation on the Feeding Behaviour of High Production Dairy Cows. Animals 2022, 12, 243. https:// doi.org/10.3390/ani12030243

Academic Editor: Wojciech Barański

Received: 16 December 2021

Accepted: 17 January 2022

Published: 20 January 2022

Publisher's Note: MDPI stays neutral with regard to jurisdictional claims in published maps and institutional affiliations.

Copyright: (c) 2022 by the authors Licensee MDPI, Basel, Switzerland. This article is an open access article distributed under the terms and conditions of the Creative Commons Attribution (CC BY) license (https:// creativecommons.org/licenses/by/ $4.0 /$ )
Simple Summary: In pasture based systems dairy cows spend more than $50 \%$ of their time grazing and ruminating, thus these behaviours require a lot of time and energy. Understanding the impact of management factors such as pasture allocation frequency on animal feeding behaviour will assist with the development of systems that support natural and efficient animal feeding behaviour. The aim of this study was to investigate the effect of frequency of fresh pasture allocation, three treatments offering fresh pasture every 12, 24 or 36 hours on the grazing and ruminating behaviours of high-yielding dairy cows. Animals displayed diurnal feeding patterns, irrespective of treatment, concentrating the majority of their grazing activity during the day $(90 \%)$ and their ruminating activity during the night (73\%). Peak grazing activity coincided with fresh pasture allocation in the $12 \mathrm{~h}$ and $24 \mathrm{~h}$ treatments. However, in the $36 \mathrm{~h}$ treatment peak grazing activity did not correspond with the allocation of fresh pasture and grazing was more evenly distributed over each $24 \mathrm{~h}$ period, indicating the animals' inability to anticipate feed. Increased competition for resources in the $12 \mathrm{~h}$ treatment likely resulted in the greater grazing and ruminating times exhibited by primiparous animals, indicating greater overall energy expenditure on feeding behaviour.

\begin{abstract}
For ruminants, grazing and ruminating activities are essential in nutrient capture and ultimately animal performance however these activities can demand significant time and energy. This study evaluated the effect of three different pasture allocation frequencies (PAF's; 12, 24 and $36 \mathrm{~h}$ ) on the feeding behaviour of grazing dairy cows. Eighty-seven spring calving dairy cows were divided into three treatments. Animals were rotationally grazed with fixed paddock sizes of 0.14 ha, 0.28 ha and 0.42 ha paddocks for the $12 \mathrm{~h}, 24 \mathrm{~h}$ and $36 \mathrm{~h}$ treatments, respectively. Animals (14 per treatment) were fitted with behaviour halters that monitored feeding activity. Diurnal feeding patterns were evident for all animals irrespective of PAF, concentrating the majority of grazing during daytime $(90 \%)$ and ruminating activity during night (73\%). Treatment significantly affected feeding behavior patterns. Peak grazing activity coincided with fresh pasture allocation in the $12 \mathrm{~h}$ and $24 \mathrm{~h}$ treatments. In the $36 \mathrm{~h}$ treatment, grazing was more evenly distributed over each $24 \mathrm{~h}$ period with peak grazing activity witnessed daily between 17:00 and 19:00 regardless of fresh pasture allocation, suggesting lack of anticipation of fresh feed delivery. In the $12 \mathrm{~h}$ treatment primiparous animals exhibited greater grazing and ruminating activity relative to multiparous animals in the $12 \mathrm{~h}$ treatment highlighting the impact of competition for resources within each feed on lower dominance animals.
\end{abstract}

Keywords: dairy cows; grazing management; animal behavior; grazing; ruminating; parity

\section{Introduction}

Fresh pasture remains a large component in dairy cow diets within many temperate regions. However, achieving high levels of dry matter intake (DMI) in pasture based systems remains a challenge, creating difficulty in meeting the nutritional requirements of 
high production dairy cows in pasture based systems [1]. An animal's ability to meet its nutritional requirement in a pasture based system is influenced by a range of plant and animal factors for example the nutritional value of the pasture [2], animal breed [3], and pasture quantity [4], additionally nutritional requirement can vary significantly between individual animals. However, animal grazing behaviour also has an important role to play in dictating both nutrient intake and energy expenditure with the balance between these ultimately determining the energy available for milk production.

Lactating dairy cows typically spend up to $15 \mathrm{~h} \mathrm{cow}^{-1}$ day $^{-1}$ eating and ruminating $[5,6]$. This activity is associated with a considerable level of energy expenditure, for example Susenbeth, et al. [7], determined the energy costs of eating and ruminating behaviour to be 30 and $9 \mathrm{~J} \mathrm{~min}^{-1} \mathrm{~kg}^{-1}$ of body weight, respectively for steers fed indoors. Additionally, Osuji [8] suggested maintenance energy requirements for grazing animals could be $25-50 \%$ greater relative to housed animals as a result of the increased physical activity associated with walking and harvesting pasture. Dohme-Meier, et al. [9] observed this effect, reporting a 19\% increase in energy expenditure with animals actively grazing relative to animals fed fresh grass indoors during a six hour measurement period, due to reduced physical activity in housed animals. In addition, energy expenditure of animals can vary depending on the condition of the terrain underfoot, with up to four fold increases in animal energy expenditure observed when animals are walking on soft or waterlogged terrain compared to firm ground, highlighting the potential effect of external factors further impacting energy expenditure in pasture based systems [10].

The motivation for an animal to express feeding behaviours such as grazing and ruminating within pasture systems can be influenced by multiple factors including stage of lactation, parity and milk output. Within commercial herd environments, grazing groups often consist of a collection of individual animals with varying milk yield and stage of lactation, impacting nutrient demand for both animal maintenance and milk production. Although pasture allocation rates are often described on an individual cow basis within academic literature (e.g., $15 \mathrm{~kg}$ dry matter (DM) $\mathrm{cow}^{-1}$ day $^{-1}$ ), in practice this allocation rate is applied to a whole grazing mob, allowing animals the ability to consume above or below the desired rate of intake. This, coupled with the typical variation in individual animal nutritional demands within a grazing mob may create significant levels of competition and variability in intake rates and pasture quality.

Indeed within a herd, primiparous animals are often subject to high levels of competition and they are often classified as subordinate due to their lower live weight and lactation number [11,12]. Studies in indoor systems, where competition for resources can often be high, have shown subordinate cows alter their periods of feed consumption, in particular reducing feeding time after fresh feed delivery, resulting in receipt of less aggressive behaviours but consumption of poorer quality feedstuffs [13]. To date, limited research has investigated the interaction effects of pasture management methods on the variations in feeding behaviour with animal parity group. Further understanding variations in animal feeding behaviour will allow for the development of strategies that support efficient feeding patterns for all animals, subsequently maximising individual animal performance.

Motivation to feed and feeding behaviour is also strongly influenced by management aspects such as feed availability [14,15], the presence of periods of feed deprivation [16-18], and the frequency of feed delivery [17]. For example Dale, et al. [15] documented a greater number of mastication bites during rumination when dairy cows were offered high pasture allowance, whilst DeVries, et al. [17] reported a significant increase in feeding time immediately following the delivery of fresh feed. Hence, management of grazing resources can significantly impact animal behaviour and consequently animal performance.

Pasture allocation frequency (PAF) is the rate that fresh pasture is offered to dairy cows typically within a rotational grazing system. This management technique may potentially influence hunger, feed availability and competition within the herd. Hence, PAF may potentially alter the frequency, intensity and temporal distribution of grazing and ruminating events thus likely altering nutrient supply to grazing animals. To date 
research on PAF has focused on relatively high [19] or low frequencies [5] of fresh pasture allocation, that are not commonly practice in dairying systems. In addition, the effect of PAF on inter-animal variations on grazing behaviour are poorly understood.

Consequently, the objective of this study was to understand the influence of commercially practiced frequencies of fresh pasture allocation on the feeding behaviour of lactating dairy cows and its interaction with parity grouping.

\section{Materials and Methods}

The experiment was conducted during 2019 at the Agri-Food and Biosciences Institute, Hillsborough, County Down, Northern Ireland, UK ( $\left.54^{\circ} 27^{\prime} \mathrm{N} ; 06^{\circ} 04^{\prime} \mathrm{W}\right)$. Experimental procedures in this study were conducted under an experimental license granted by the Department of Health, Social Services and Public Safety for Northern Ireland in accordance with the Animals Scientific Procedures Act 1986. The experimental licence was granted following a review and approval of the proposed study by the Agri-Food and Bioscience Institute Animal Welfare and Ethics Review Board. The experiment consisted of two time periods; Period One (P1; 11 May-10 July) and Period Two (11 August-10 October). A complimentary paper Pollock, et al. [20] outlines details of animal performance and pasture utilisation. This paper focuses on the effect of pasture allocation frequency on animal behaviour during Period Two.

Weather during the behaviour recording period ( 8 to 20 September) was atypical for this time of year. Average air temperature was $13.6^{\circ} \mathrm{C}, 1.1{ }^{\circ} \mathrm{C}$ higher than the previous five year (2013-2017) average for September. Accumulated rainfall during the 12 day measurement period was $27.6 \mathrm{~mm}$ with daily rainfall accumulation ranging between $0-5.8 \mathrm{~mm}$. Monthly average rainfall accumulation for the previous five years for September was $55.7 \mathrm{~mm}$.

\subsection{Animal and Grazing Management}

A total of 87 lactating dairy cows were split into three treatment groups $(n=29)$. Each group consisted of eight primiparous and 21 multiparous animals. Treatment groups were balanced for calving date and lactation number with a mean of 4 February (s.d., $18.3 \mathrm{~d}$ ) and 2.5 lactations (s.d., $1.30 \mathrm{~d}$ ), respectively. Treatments were balanced prior to period two for pre-experimental milk yield [mean $27.6 \mathrm{~kg} \mathrm{cow}^{-1} \mathrm{day}^{-1}$ (s.d., 7.40)], live weight [mean $606 \mathrm{~kg}$, (s.d. $62.1 \mathrm{~kg}$ )], body condition score [mean 2.42, (s.d., 0.157)], milk predicted transmitting ability (PTA) [mean $200 \mathrm{~kg}$, (s.d. $141.9 \mathrm{~kg}$ )] and kilograms of fat plus protein PTA [mean $26.3 \mathrm{~kg}$, (s.d. $7.09 \mathrm{~kg}$ )]. Balanced groups were assigned to one of the three pasture allocation frequency treatments, with fresh pasture allocated every; $12 \mathrm{~h}, 24 \mathrm{~h}$ or $36 \mathrm{~h}$. The grazing area consisted predominately of perennial ryegrass (Lolium perenne L.) with an average sward age of five years old. Seven grazing blocks were divided into three plots $(0.84 \mathrm{ha})$, each plot consisting of either; six $12 \mathrm{~h}$ paddocks $(0.14 \mathrm{ha})$, three $24 \mathrm{~h}$ paddocks $(0.28 \mathrm{ha})$ or two $36 \mathrm{~h}$ paddocks $(0.42 \mathrm{ha})$. Stocking rate over the course of the study was the same for all treatments $\left(4.9 \mathrm{cows}^{-1} \mathrm{ha}^{-1}\right)$ because animals on each treatment grazed the same area over each $72 \mathrm{~h}$ grazing block however, physical stocking rate in each paddock was 207, 104 and 69 cows' hectare $^{-1}$ for the $12 \mathrm{~h}, 24 \mathrm{~h}$ and $36 \mathrm{~h}$ treatments respectively. Animals rotationally grazed paddocks and pasture allocation during the first feed of each treatment was 22.5, 15 and $7.5 \mathrm{~kg} \mathrm{DM} \mathrm{cow}^{-1}$ day $^{-1}$ for the $36 \mathrm{~h}, 24 \mathrm{~h}$ and $12 \mathrm{~h}$ treatments respectively. This equates to each treatment receiving a daily pasture allocation rate of $15 \mathrm{~kg} \mathrm{DM} \mathrm{cow}^{-1} \mathrm{day}^{-1}$. Within the $24 \mathrm{~h}$ treatment, fresh pasture was offered post afternoon milking. Pre and post-grazing height was determined using a rising plate meter (RPM; Jenquip EC10 Electronic Platemeter, Feilding, New Zealand). Pasture quality was determined twice weekly using near infrared spectroscopy (NIRS). Animals were milked twice daily between 05:00 and 07:00 $\mathrm{h}$ and 15:00 and 17:00 h. Concentrates were offered during every milking to all animals at an average daily feed rate of $5.5 \mathrm{~kg}^{\mathrm{day}}{ }^{-1}$ and $7.0 \mathrm{~kg} \mathrm{day}^{-1}$ for primiparous and multiparous animals, respectively. The concentrate comprised of ( $\mathrm{g} \mathrm{kg}^{-1}$ as fed basis) soya hulls (187), maize meal (160), wheat (150), Hi-pro 
soya bean meal (125), rape seed meal (90), molasses (70), distillers grains (60), pollard (57), citrus-pulp (40), rumen-protected fat (20) and minerals/vitamins (41).

Animal performance measurements were taken throughout the experiment including daily milk yield, weekly milk quality, total milk output and live weight change, as described by Pollock, et al. [20].

\subsection{Animal Behaviour}

Within the three treatment groups a subset of animals were selected for behavioural measurements. A total of 42 animals were selected $(n=14$ per treatment) and balanced according to the initial parameters (pre-experimental yield, days in milk, live weight, PTA of milk yield, fat and protein). Each subset of 14 animals from each treatment consisted of four primiparous and ten multiparous animals. Animals were fitted with grazing and ruminating behaviour monitoring equipment (RumiWatch; ITIN + HOCH, Switzerland) for a period of 12 days (8-20 September). The equipment consisted of a halter equipped with an oil-filled tube with a built-in pressure sensor, a 3-axis accelerometer, data logger and two 3.6 V batteries. The oil-filled tube was placed over the bridge of the animal's nose, the pressure within the oil-filled tube altered with jaw movements. These pressure signatures and acceleration patterns were collected at a frequency of $10 \mathrm{~Hz}$ resolution. Raw data was stored on 4 GB SD memory card and downloaded after the 12 day recording period. As detailed and validated by Werner, et al. [21], specialist software (RumiWatch Converter version V0.7.4.5) was used to classify pressure and acceleration data into a range of grazing and ruminating variables, producing one-hour data summaries (Table 1). Halters were reviewed twice daily to ensure animals did not have any abrasions.

Table 1. Grazing behaviour parameters recorded using the RumiWatch sensor [22].

\begin{tabular}{ccc}
\hline Behaviour Variable & $\begin{array}{c}\text { Variable in RumiWatch } \\
\text { System * }\end{array}$ & Variable Description \\
\hline Grazing time $\left(\min \operatorname{cow}^{-1} \mathrm{~h}^{-1}\right)$ & EAT1TIME & $\begin{array}{c}\text { Time spent eating (prehension } \\
\text { bites and mastication chews in } \\
\text { the downward position) }\end{array}$ \\
\hline Ruminating time $\left(\mathrm{min} \mathrm{cow}^{-1} \mathrm{~h}^{-1}\right)$ & RUMINATETIME & $\begin{array}{c}\text { Time spent ruminating } \\
\text { per hour }\end{array}$ \\
\hline Number of boli $\left(n . \mathrm{cow}^{-1} \mathrm{~h}^{-1}\right)$ & BOLUS & $\begin{array}{c}\text { Number of rumination } \\
\text { boluses per hour }\end{array}$ \\
\hline Chews per bolus $(n$. bolus & & $\begin{array}{c}\text { Number of chews per } \\
\text { rumination bolus }\end{array}$ \\
\hline * Variable as it appears in the RumiWatch System. & CHEWSPERBOLUS &
\end{tabular}

\subsection{Statistical Analysis}

Data from the halter was recorded from 17:00 on 8th September to 17:00 on 20th September. This was split into four $72 \mathrm{~h}$ grazing periods, each treated as a replicate grazing period. Within each $72 \mathrm{~h}$ period, data was compressed into two hour intervals to assist with data handling. The calculated variables were analysed using Genstat (Genstat Sixteenth Edition, Lawes Agricultural Trust, Rothamsted, UK) with a repeated measures design using the restricted maximum likelihood (REML) estimation method with the correlation between time points assessed with an autoregressive model of order 1. Animal was fitted as the subject factor with two hour time period as the time factor. A factorial arrangement of Time, Parity Group and Treatment were fitted as fixed effects. If the overall model terms in the fixed effects were significant $(p<0.05)$, the Bonferroni method a two-tailed post-hoc tests for multiple comparisons was used to determine differences between individual effects. For the purpose of this paper, day time was considered to be 05:00 to 21:00 and night time 21:00 to 05:00, these times were selected as they corresponded with dusk and early morning milking. 
Previous studies have questioned the merit of using individual animals as replicates in grazing experiments. However, the use of multiple groups may have downfalls as small groups of animals behave differently to large groups. Rind, et al. [23] documented cows in small groups (four animals) stayed closer to the neighbouring cows, moved their head more rapidly from side to side during grazing and spent more time grazing compared to cows in larger groups (16 animals). The study also highlighted animals' in larger groups were more aggressive, maintained greatest distance from other animals and had faster rate of stepping while grazing, the authors attributed these differences to an increased inter-animal competition in larger groups. In the present study groups were not replicated as larger groups better represented commercial farming systems and the inter-animal competition exhibited within their herds.

\section{Results}

\subsection{Feeding Behaviour}

Average grazing and ruminating times were $540 \mathrm{~min} \mathrm{cow}^{-1}$ day $^{-1}$ and $330 \mathrm{~min} \mathrm{cow}^{-1}$ day $^{-1}$, respectively across all three PAFs. All treatments exhibited strong diurnal feeding patterns with on average $90 \%$ of grazing time occurring during the day and $73 \%$ of ruminating time occurring during night time hours. Grazing time was 22.3, 21.9 and $23.3 \mathrm{~min} \mathrm{cow}^{-1} \mathrm{~h}^{-1}$ for the $12 \mathrm{~h}, 24 \mathrm{~h}$ and $36 \mathrm{~h}$ treatments, respectively with grazing time significantly greater for animals in the $36 \mathrm{~h}$ treatment relative to the $12 \mathrm{~h}$ and $24 \mathrm{~h}$ treatments $(p<0.001)$.

Peak grazing time per hour was evident for all treatments between the hours of 17:00 and 19:00 over the $72 \mathrm{~h}$ grazing block, averaging 54 min grazing cow ${ }^{-1} \mathrm{~h}^{-1}$. However, in the following two hour period (19:00-21:00) grazing time was significantly longer $\left(+15 \mathrm{~min} \mathrm{cow}^{-1} \mathrm{~h}^{-1}\right)$ for animals in the $24 \mathrm{~h}$ PAF relative to the other two treatments $\left(p<0.001\right.$; Figure 1). Both the $12 \mathrm{~h}\left(51 \mathrm{~min} \mathrm{cow}^{-1} \mathrm{~h}^{-1}\right)$ and $36 \mathrm{~h}\left(44 \mathrm{~min} \mathrm{cow}^{-1} \mathrm{~h}^{-1}\right)$ treatments exhibited an additional grazing peak between 07:00 and 09:00 which was not evident in the $24 \mathrm{~h}$ treatment $\left(27 \mathrm{~min} \mathrm{cow}^{-1} \mathrm{~h}^{-1} ; p<0.001\right.$; Figure 1$)$. Animals in the $36 \mathrm{~h}$ treatment exhibited greater distribution of grazing throughout the daytime relative to the $12 \mathrm{~h}$ or $24 \mathrm{~h}$ PAF. This was particularly evident between the hours of 11:00 and 13:00 with the $36 \mathrm{~h}$ treatment recording a significantly higher proportion of time spent grazing $\left(38 \mathrm{~min} \mathrm{cow}^{-1} \mathrm{~h}^{-1}\right)$ than the $12 \mathrm{~h}\left(22 \mathrm{~min} \mathrm{cow}^{-1} \mathrm{~h}^{-1}\right)$ or the $24 \mathrm{~h} \mathrm{PAF}$ $\left(17\right.$ min $\operatorname{cow}^{-1} \mathrm{~h}^{-1} ; p<0.001$; Figure 1) treatments. During night time, grazing time was notably lower for all treatments (average $7 \mathrm{~min} \mathrm{cow}^{-1} \mathrm{~h}^{-1}$ ) relative to daytime grazing (average $30 \mathrm{~min} \mathrm{cow}^{-1} \mathrm{~h}^{-1}$ ). However, animals in the $24 \mathrm{~h}$ treatment appeared to exhibit a grazing bout between the hours of 23:00 and 01:00 which was not evident in the other PAF treatments. During this time animals in the $24 \mathrm{~h}$ PAF exhibited a grazing time of $27 \mathrm{~min}$ $\operatorname{cow}^{-1} \mathrm{~h}^{-1}$; significantly longer relative to animals in the $12 \mathrm{~h}\left(6 \mathrm{~min} \mathrm{cow}^{-1} \mathrm{~h}^{-1}\right)$ or $36 \mathrm{~h}$ $\left(9\right.$ min cow $\left.^{-1} \mathrm{~h}^{-1}\right)$ treatments $(p<0.001$; Figure 1$)$.

Average ruminating time decreased with decreasing frequency of fresh pasture allocation with ruminating times of 15.0, 13.7 and $12.6 \mathrm{~min} \mathrm{cow}^{-1} \mathrm{~h}^{-1}$ for the $12 \mathrm{~h}, 24 \mathrm{~h}$ and $36 \mathrm{~h}$ treatments, respectively with significances observed between each treatment $(p<0.001$; Table 2). However, again diurnal trends were evident across all three treatments with aver-

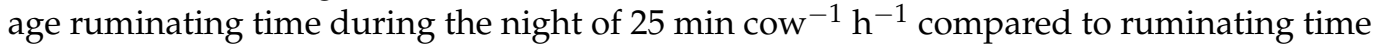
during the day averaging $8 \mathrm{~min} \mathrm{cow}^{-1} \mathrm{~h}^{-1}$ (Figure 1). Ruminating time was lowest for all treatments between the hours of 17:00 and 19:00, recording on average 0.5 min cow ${ }^{-1} \mathrm{~h}^{-1}$ ruminating, this corresponds with the peak observed in grazing activity. Periods of peak rumination activity occurred during hours when grazing activity was low and vice versa.

Animals in the $12 \mathrm{~h}$ PAF displayed significantly longer ruminating time $\left(9 \mathrm{~min} \mathrm{cow}^{-1} \mathrm{~h}^{-1}\right)$ between 19:00 and 01:00 compared to the 24 h PAF $(p<0.001$ : Figure 1). Contrastingly at 07:00, animals in the $24 \mathrm{~h}$ treatment ruminated $10 \mathrm{~min} \mathrm{cow}^{-1} \mathrm{~h}^{-1}$ longer on average relative to the $12 \mathrm{~h}$ PAF ( $p<0.001$; Figure 1 ). Animals in the $36 \mathrm{~h}$ treatment did not exhibit the same peaks in ruminating activity relative to the other two PAF's (Figure 1). This was most notable between 11:00 to 13:00 when ruminating time was significantly lower $\left(9 \mathrm{~min} \mathrm{cow}^{-1} \mathrm{~h}^{-1}\right)$ for animals in the $36 \mathrm{~h}$ treatment relative to the other two PAF's 
$(p<0.001$; Figure 1). In addition, between 07:00 and 15:00 ruminating time was $7 \mathrm{~min}$ cow $^{-1} \mathrm{~h}^{-1}$ shorter for animals in the $36 \mathrm{~h}$ treatment compared to the $24 \mathrm{~h}$ PAF. Furthermore, ruminating time between 21:00 and 03:00 was $5 \mathrm{~min} \mathrm{cow}^{-1} \mathrm{~h}^{-1}$ shorter for animals in the $36 \mathrm{~h}$ PAF relative to the animals in the $12 \mathrm{~h}$ PAF (Figure 1 ).
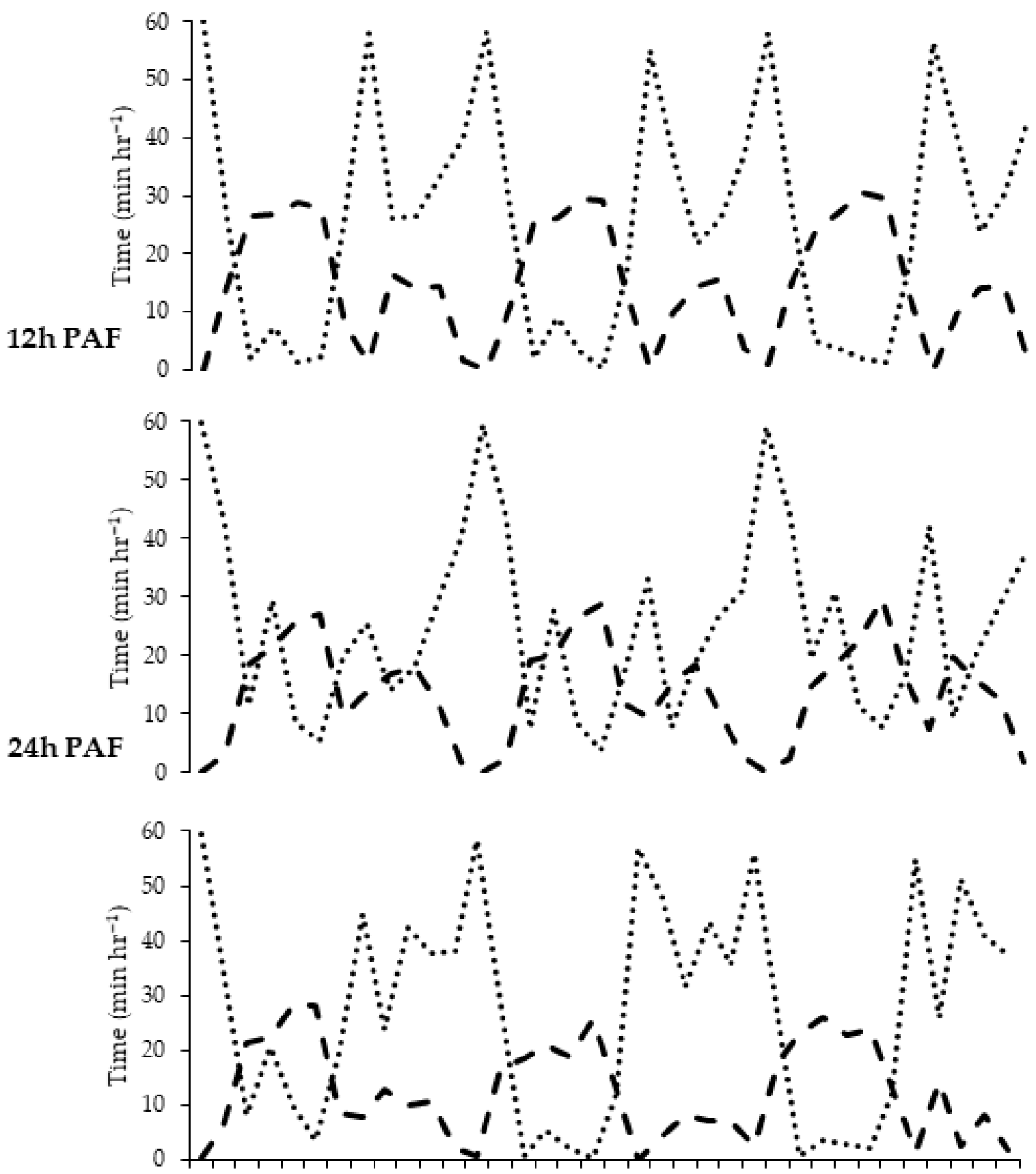

36h PAF

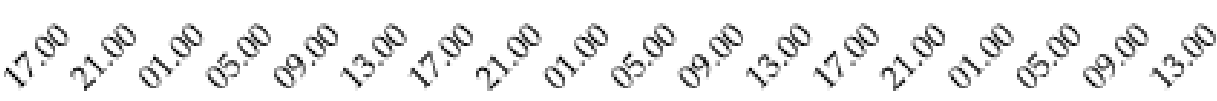

Time over the 72 hour grazing block

Figure 1. Impact of pasture allocation frequency $(12,24$ or $36 \mathrm{~h}$ ) on average grazing (dotted line, $\bullet \bullet \bullet$ ) and ruminating time (dashed line, - - - ) during a $72 \mathrm{~h}$ grazing period. 
Table 2. The effect of parity, pasture allocation frequency and interaction effects on animal grazing and ruminating behaviour.

\begin{tabular}{|c|c|c|c|c|c|c|c|c|c|c|}
\hline & \multicolumn{3}{|c|}{ Primiparous Animals } & \multicolumn{3}{|c|}{ Multiparous Animals } & \multirow[b]{2}{*}{ SED $^{4}$} & \multicolumn{3}{|c|}{ Significance } \\
\hline & $12 \mathrm{~h}^{1}$ & $24 \mathrm{~h}^{2}$ & $36 \mathrm{~h}^{3}$ & $12 \mathrm{~h}$ & $24 \mathrm{~h}$ & $36 \mathrm{~h}$ & & Parity & Treatment & $\begin{array}{c}\text { Interaction } \\
\text { Effect }\end{array}$ \\
\hline $\begin{array}{c}\text { Grazing time } \\
\left(\min _{\text {cow }}^{-1} \mathrm{~h}^{-1}\right)\end{array}$ & $24.3^{c}$ & $22.4^{b, c}$ & $22.3^{b, c}$ & $20.3^{a}$ & $21.4^{\mathrm{a}, \mathrm{b}}$ & $24.3^{d}$ & 0.61 & 0.004 & $<0.001$ & $<0.001$ \\
\hline $\begin{array}{l}\text { Rumination time } \\
\left(\mathrm{min} \mathrm{cow}^{-1} \mathrm{~h}^{-1}\right)\end{array}$ & $15.8^{c}$ & $13.2^{a, b}$ & $12.4^{\mathrm{a}}$ & $14.2^{b}$ & $14.2^{\mathrm{b}}$ & $12.8^{\mathrm{a}}$ & 0.47 & 0.951 & $<0.001$ & $<0.001$ \\
\hline $\begin{array}{l}\text { Number of boli } \\
\left(\text { no. cow }{ }^{-1} \mathrm{~h}^{-1}\right)\end{array}$ & $17.2^{\mathrm{c}}$ & $14.3^{\mathrm{a}, \mathrm{b}}$ & $13.0^{\mathrm{a}}$ & $15.7^{b, c}$ & $15.4^{b}$ & $13.9^{\mathrm{a}}$ & 0.55 & 0.635 & $<0.001$ & 0.002 \\
\hline $\begin{array}{l}\text { Chews per bolus } \\
\text { (no bolus }{ }^{-1} \text { ) }\end{array}$ & $37.7^{\mathrm{c}}$ & $32.0^{\mathrm{a}, \mathrm{b}}$ & $33.4^{\mathrm{b}}$ & $31.5^{a, b}$ & $31.7^{\mathrm{a}, \mathrm{b}}$ & $29.9^{\mathrm{a}}$ & 1.15 & $<0.001$ & 0.006 & 0.002 \\
\hline
\end{tabular}

${ }^{1} 12 \mathrm{~h}=12 \mathrm{~h}$ allocations. ${ }^{2} 24 \mathrm{~h}=24 \mathrm{~h}$ allocations. ${ }^{3} 36 \mathrm{~h}=36 \mathrm{~h}$ allocations. ${ }^{4} \mathrm{SED}=$ standard error of differences of the treatment $x$ parity interaction means. Within a row means are associated with treatment $x$ parity interactions. Means with different superscript letters differ at $p<0.05$ based on the two-tailed post-hoc analysis determined by the Bonferroni method.

\subsection{Interaction of Frequency of Pasture Allocation and Animal Parity Group}

Primiparous animals in the $12 \mathrm{~h}$ treatment exhibited the longest grazing time, grazing for 48 min cow $^{-1}$ day $^{-1}$ longer relative to primiparous animals in the $24 \mathrm{~h}$ and $36 \mathrm{~h}$ treatments. In contrast, grazing time in multiparous animals increased with decreasing PAF, with multiparous animals in the $36 \mathrm{~h}$ PAF grazing for significantly longer relative to multiparous animals in the $12 \mathrm{~h}$ and $24 \mathrm{~h}$ treatments $(p<0.001$; Table 2). An extra grazing session between 11:00 and 13:00 was exhibited for both primiparous and multiparous animals in the $36 \mathrm{~h}$ PAF animals grazed for 15 and $21 \mathrm{~min} \mathrm{cow}^{-1} \mathrm{~h}^{-1}$ longer, respectively compared to their parity counterparts in the two other treatments $(p<0.001)$.

Although feeding behaviour patterns over the $72 \mathrm{~h}$ grazing block were similar for parity groups within treatments, significant treatment and parity group interactions were observed (Table 2). Within the $12 \mathrm{~h}$ treatment, grazing time was significantly longer for primiparous animals relative to multiparous animals $(p<0.001$; Table 2). Contrastingly, the opposite effect was exhibited in the $36 \mathrm{~h} \mathrm{PAF}$ with grazing time $2 \mathrm{~min} \mathrm{cow}{ }^{-1} \mathrm{~h}^{-1}$ shorter for primiparous relative to multiparous animals $(p<0.001$; Table 2). Grazing time in the $24 \mathrm{~h}$ PAF was similar for both parity groups (Table 2).

Treatment and parity group interactions were also evident for rumination activity. Primiparous animals in the $12 \mathrm{~h}$ PAF had a significantly longer average ruminating time ( 3 min cow $^{-1} \mathrm{~h}^{-1}$ ) compared to primiparous animals in the $24 \mathrm{~h}$ and $36 \mathrm{~h}$ PAF $(p<0.001$; Table 2). This difference was clearly identifiable during night time (Figure 2). In addition, decreasing the frequency of pasture allocation resulted in a decrease in the number of boli regurgitated per hour in primiparous animals, with primiparous animals in the $12 \mathrm{~h}$ PAF regurgitating a significantly higher number of boli relative to primiparous animals in the $24 \mathrm{~h}$ and $36 \mathrm{~h}$ treatments $(p=0.002$; Table 2$)$. Similarly, chews per bolus were significantly greater for primiparous animals in the $12 \mathrm{~h}$ PAF chewing each boli on average 5 times more, relative to primiparous animals in the $24 \mathrm{~h}$ and $36 \mathrm{~h}$ treatments ( $p=0.002$; Table 2 ).

Ruminating time for multiparous animals in the $36 \mathrm{~h}$ treatment was significantly lower $\left(1.4 \mathrm{~min} \mathrm{cow}^{-1} \mathrm{day}^{-1}\right)$ relative to the multiparous animals $12 \mathrm{~h}$ and $24 \mathrm{~h}(p<0.001$; Table 2). Similarly, number of boli regurgitated per day was $12 \%$ lower for multiparous animals in the $36 \mathrm{~h}$ treatment relative to multiparous animals in the $12 \mathrm{~h}$ and $24 \mathrm{~h}$ treatments $(p=0.002$; Table 2). 


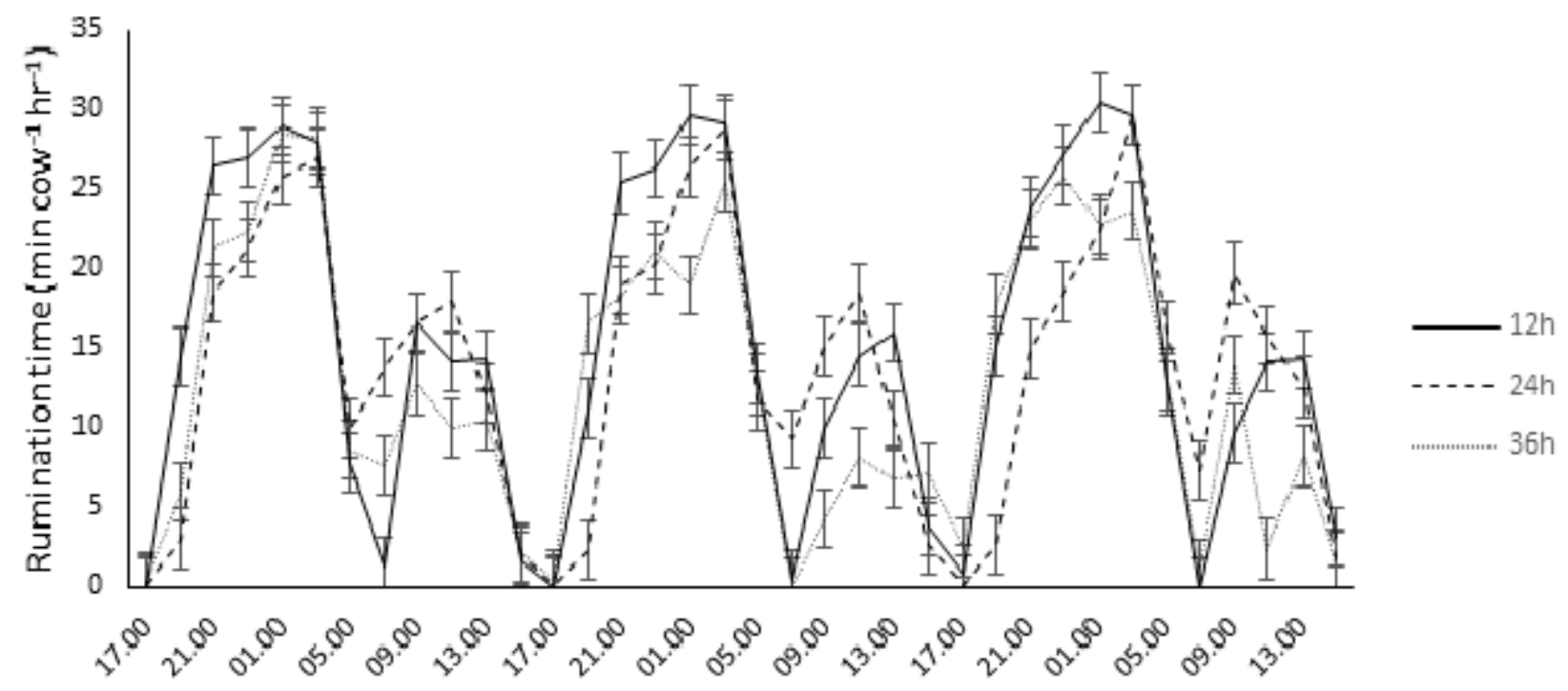

Time over the 72 hour grazing block

Figure 2. Ruminating time of primiparous animals offered fresh pasture every 12, 24 and 36 h over a $72 \mathrm{~h}$ grazing block.

Additionally, within treatment differences in rumination activity were observed. Primiparous animals in the $12 \mathrm{~h}$ PAF exhibited a significantly longer ruminating time (38.4 min cow $^{-1}$ day $^{-1} ; p<0.001$ ) relative to multiparous animals (Table 2). Likewise, chews per bolus were $20 \%$ greater in primiparous animals compared to multiparous animals in the $12 \mathrm{~h} \mathrm{PAF}$, this increase was particularly evident following the two main grazing sessions in the $12 \mathrm{~h} \mathrm{PAF} \mathrm{(} p=0.002$; Figure 3 ). Within the $36 \mathrm{~h} \mathrm{PAF}$, ruminating time and number of boli regurgitated was similar for both primi- and multiparous animals (Table 2). However, primiparous animals in the $36 \mathrm{~h}$ PAF exhibited $10 \%$ more chews per bolus relative to multiparous animals ( $p=0.002$; Table 2$)$. Differences were not observed between parity groups within the $24 \mathrm{~h}$ PAF (Table 2).

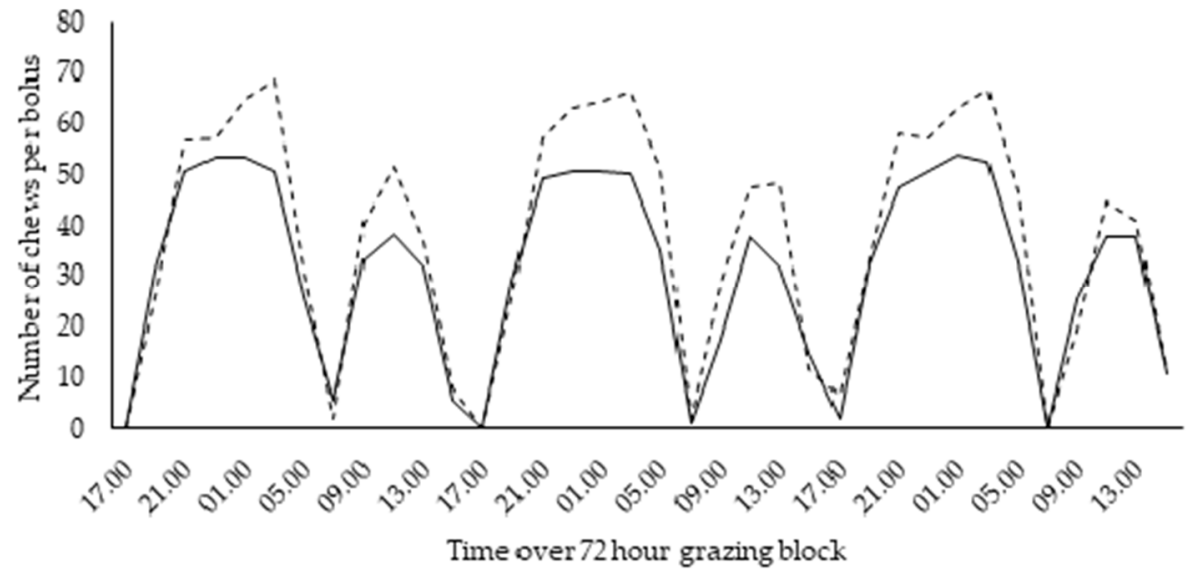

Figure 3. Number of chews per a rumination bolus for primiparous (dashed line) and multiparous animals (solid line) in the $12 \mathrm{~h}$ PAF over the $72 \mathrm{~h}$ grazing block.

\section{Discussion}

The objective of this study was to understand the impact of frequency of fresh pasture allocation on the feeding behaviour of lactating dairy cows. In addition, following the observed parity and PAF interaction effects on animal performance reported in a complimentary paper [20], this paper aims to investigate parity group and PAF interactions on animal feeding behaviour. Pollock, et al. [20] observed primiparous animals in 
the 36 h PAF exhibited significantly $(p<0.001)$ greater milk energy output, on average $10.9 \mathrm{MJ} \mathrm{cow}^{-1}$ day $^{-1}$ higher compared to primiparous animals in the $12 \mathrm{~h}$ and $24 \mathrm{~h}$ PAF.

\subsection{Daily Feeding Patterns}

Average daily grazing time and ruminating time in the present study is representative of high production Holstein-Friesian dairy cows within full-time grazing systems and is comparable with that noted by others [6,24], highlighting the significant energy and time requirements associated with nutrient capture in grazing systems. The concentration of grazing activity during the day has been widely reported with grazing from dusk to dawn typically accounting for less than $15 \%$ of total grazing time and thus contributing minimally to total DMI $[25,26]$. Linnane, et al. [27] suggested low levels of grazing during the night may reflect the greater difficulty of the animal to selectivity graze in the dark. Additionally, the preference for animals in the present study to concentrate the majority of their rumination activity during the night is in agreement with previous indoor [28] and grazing [29] studies on lactating dairy cows. These feeding patterns occurred across all three treatments confirming diurnal feeding behaviour exists in pasture systems irrespective of the management method imposed. Previous literature has similarly observed diurnal feeding patterns under a number of different management methods including restricted pasture [29] and timing of pasture allocation [30].

\subsection{Influence of PAF on Animal Feeding Behaviour}

Contrary to the present experiment, previous studies have reported no effect of PAF on grazing time [5,31], this may be due to the relatively low [5] and high [31] frequencies of pasture allocation investigated. and the relatively high pasture allowances $\left(\sim 40 \mathrm{~kg} \mathrm{DM}^{-1} \mathrm{cow}^{-1} \mathrm{~d}^{-1}\right)$ offered by Abrahamse, et al. [5] and Dalley, et al. [31] relative to the present study. The high pasture allowance offered may not fully represent competition within a commercial grazing system thus pasture allocation may have had a greater impact on grazing time than the frequency of fresh pasture allocation. However similar to the studies of Verdon, et al. [19] and Abrahamse, et al. [5], PAF in the present study had a significant impact on the pattern of daily grazing activity.

Literature has widely acknowledged allocation of fresh feed motivates animals to eat, thus the greatest proportion of time attributed to this activity often occurs immediately after the delivery of fresh feed, as observed in studies offering a total mixed ration (TMR) [32] and pasture [19]. This effect was observed in both the $12 \mathrm{~h}$ and $24 \mathrm{~h}$ PAF with the longest grazing period(s) occurring shortly after the one ( $24 \mathrm{~h})$ or two (12 h) daily allocations of fresh pasture.

Animals in the $24 \mathrm{~h}$ PAF spent a longer proportion of time grazing when offered fresh pasture in the afternoon compared to animals in the $12 \mathrm{~h}$ PAF. An indoor study offering dairy cows TMR similarly witnessed reducing allocations from twice to once daily resulted in more animals eating for longer when TMR was offered once daily [17]. However, this concentration of feeding activity during certain periods of the day may have a greater effect in pasture based systems compared to indoor systems as pasture nutritive value varies throughout the day. Orr, et al. [33] reported pasture offered in the evening $(19: 30 \mathrm{~h})$ displayed a greater nutritive value with an increase in DM (+9\%), water soluble carbohydrate (WSC) $(+2.7 \%)$ and starch $(+1.1 \%)$ concentrations compared to pasture offered in the morning $(07: 30 \mathrm{~h})$. Subsequently evening allocations have been associated with improved performance of beef [34] and dairy [35] cows. In addition to improved nutritive value, pasture biochemical properties alter throughout the day. Plant toughness reduces from dawn to dusk and this is thought to increase the rate of particle breakdown during digestion, subsequently impacting on animal grazing behaviour with a more rapid particle breakdown increasing rumen throughput and encouraging further grazing activity [36].

Contrastingly, to the $12 \mathrm{~h}$ and $24 \mathrm{~h}$ PAF the greatest proportion of time spent grazing in the $36 \mathrm{~h}$ PAF did not always correspond with fresh pasture allocation. Although peak 
grazing time was observed daily between 17:00 and 19:00, this only coincided with fresh pasture allocation once every three days. Phillips, et al. [37] observed this similar effect with dairy cows offered TMR indoors on alternate days with animals displaying similar feeding behaviour on feeding and non-feeding days. The authors suggested animals fed at intervals greater than $26 \mathrm{~h}$ could not anticipate delivery of fresh feed resulting less disturbance of animal feeding behaviour (due to periods of feed restriction) and subsequently an increase in TMR intake and milk yield. In the present study, animals in $36 \mathrm{~h}$ PAF displayed a greater distribution of daily grazing activity, more representative of that of set stocking [38] The greater distribution of grazing behaviour and lack of grazing peaks observed when fresh pasture was offered is likely a result of the animals' inability to anticipate delivery of fresh pasture.

A greater distribution of grazing behavior throughout a $24 \mathrm{~h}$ period has also been witnessed at high PAF. Verdon, et al. [19] noted more even hourly grazing behaviour and a subsequent decrease in ruminating time $(p<0.001)$ when pasture was offered over seven daily allocations compared to two daily allocations. Additionally, an indoor study similarly highlighted timing and frequency of TMR feeding impacted distribution of feeding activity with animals fed once daily at 08:30 exhibiting greater $(p<0.05)$ level of spontaneous feeding in the afternoon and the early evening relative to animals fed once daily at 20:30 or twice daily at 08:30 and 20:30, respectively [39]. However, all treatments displayed low levels of feed intake during the night, further demonstrating feeding activity is influenced by circadian rhythms and not only the timing of fresh feed delivery. This greater distribution of feeding activity throughout the day is hypothesized to bring benefits including the regular supply of feed to rumen and stimulation of saliva production enhancing rumen motility and subsequently stimulating the passing of digesta through the rumen allowing more efficient absorption of nutrients [40]. Dalley, et al. [31] similarly, suggested a more consistent distribution of grazing activity provides a more consistent supply of metabolites, therefore increasing the efficiency of milk synthesis. However, animal performance impacts from changing PAF have been mixed. Verdon, et al. [19] observed lower milk yields from cows allocated seven grass allocations per day compared to those offered grass twice daily while Pollock, et al. [20] in the complimentary paper noted improved performance from reducing the frequency of fresh pasture allocation from $12 \mathrm{~h}$ to $36 \mathrm{~h}$ allocations, however this was driven by greater performance from parity one animals alone. This suggests the behavioural responses to changing pasture management are multifactorial and cannot be considered in isolation.

Primiparous animals are often classed as subordinate animals due to their lower live weight, lactation number and milk production [12]. Phillips, et al. [11] observed grazing time in lactating dairy cows was negatively correlated to dominance value thus lower ranking animals in the herd such as primiparous animals tend to graze for longer. Similarly Bach, et al. [41] observed feeding time of TMR was 30 min cow $^{-1}$ day $^{-1}$ longer for primiparous animals housed with multiparous animals compared to primiparous animals housed alone. The authors attributed this time to longer periods spent sorting feedstuffs in search of higher quality forage. It is hypothesised that similar behaviours were evident in the current study with longer grazing time of primiparous animals in the $12 \mathrm{~h}$ PAF relative to multiparous animals. The smaller grazing area and lower pasture availability immediately after allocation of fresh pasture in the $12 \mathrm{~h}$ treatment, relative to the $24 \mathrm{~h}$ and $36 \mathrm{~h}$ treatments, likely resulted in greater competition for resources. Wales, et al. [42] reported lactating cows grazing perennial ryegrass pastures to consistently selected a diet significantly higher $(p<0.001)$ in crude protein $(C P)$ and lower in neutral detergent fibre (NDF) than the average pasture on offer, this is achieved through the selection of specific grazing sites. It is likely that multiparous animals displaced primiparous animals from preferential grazing sites within the pasture, and hence were able to achieve satiety sooner due to the selection of higher quality pasture compared to their younger counterparts. In contrast, it is considered that primiparous animals expended a greater amount of time browsing and selecting herbage suitable for consumption as evidenced by the greater 
grazing time. Coupled with a likely intake of less preferential, poorer quality pasture, this would have resulted in a reduction in potential energy intake, increased energy expenditure and consequently the poorer performance as described by Pollock, et al. [20].

In contrast, the similar $(24 \mathrm{~h})$ and lower $(36 \mathrm{~h})$ grazing time of primiparous animals relative to multiparous animals in these treatments suggests reduced competition for resources (space, grazing sites and pasture availability) within these treatments. Multiple indoor studies have highlighted reduced space allowance of dairy cattle results in an increase in aggressive interactions between animals [13,43]. Although grazing systems provide a much larger space allowance for each individual animal relative to indoor systems, reducing space allowance in grazing paddocks may create competition for grazing sites.

Whilst pasture is generally allocated in kilograms of dry matter per cow, in practice pasture is allocated on a herd basis rather than to an individual animal, consequently animals within herds compete for resources [22]. Offering a high pasture allowance in the first $12 \mathrm{~h}$ period $(24 \mathrm{~h}$ and $36 \mathrm{~h}$ ) and second $12 \mathrm{~h}$ period $(36 \mathrm{~h})$ results in an increased pasture availability and a greater number of grazing sites available within these allocations, increasing access to high quality pasture for lower ranking animals. Within the $12 \mathrm{~h}$ treatment a limited amount of pasture was available to animals in every feed. Kennedy, et al. [44] observed dairy cows with restricted access to pasture employed two strategies; increased bite mass and decreased handling time in order to consume feed more rapidly during grazing. Within an indoor environment Olofsson [45] reported increasing the competition for feed resulted in animals consuming feed more rapidly compared to when there was ample access to feed. Due to the limited pasture allowance available in every feed within the $12 \mathrm{~h}$ PAF, it is likely animals within the $12 \mathrm{~h}$ PAF employed these strategies to deal with the increased competition for resources.

Increased requirement for rumination activity is a result of larger particle sizes entering the rumen [46]. In the present study ruminating time and number of boli regurgitated was significantly higher in primiparous animals within the $12 \mathrm{~h}$ treatment. This is likely a result of greater competition for resources leading to higher intake rates, more rapid consumption and decreased handling of feed, consequently leading to larger particle size entering the rumen. As previously highlighted primiparous animals are generally lower social ranking within a herd thus this effect of increased competition through limited grazing sites and pasture availability, may have a greater impact on these animals. This was observed within the $12 \mathrm{~h}$ treatment as primiparous animals exhibited a greater number chews per a bolus relative to multiparous animals in the time immediately after the two main grazing sessions, further indicating rapid intake rates, reduced handling time and selection of poorer quality grazing sites for these animals.

Previous literature has reported dairy cows with longer feeding times tend to have shorter ruminating times [28,47]. Contrary to this, both grazing and ruminating time was greatest for primiparous animals in the $12 \mathrm{~h}$ treatment compared to primiparous animals in the $24 \mathrm{~h}$ and $36 \mathrm{~h}$ treatments. This suggests competition for resources may have a strong impact on overall time budget for these animals, ultimately resulting in increased energy expenditure on feeding activities and less energy available for milk production as witnessed in the corresponding paper [20]. Although primiparous animals in the $24 \mathrm{~h}$ PAF exhibited a similar average hourly feeding behaviour relative to primiparous animals in the $36 \mathrm{~h}$ PAF however as previously discussed, the greater distribution in daily grazing activity in the $36 \mathrm{~h}$ PAF the more consistent supply of metabolites for milk synthesis. This resulted in primiparous animals in the $36 \mathrm{~h}$ PAF having a milk energy output on average $10.9 \mathrm{MJ} \mathrm{cow}^{-1}$ day $^{-1}$ greater than primiparous animals in the $12 \mathrm{~h}$ and $24 \mathrm{~h}$ PAF $(p<0.001)$ [20].

The contrasting effect of PAF on grazing time in primi- and multi-parous highlights the need to examine sub-groups or individual animal behaviours relative to the whole herd to observe a truer picture and fully understand the grazing dynamics within the herd. Previously studies investigating the effect of management methods on animals behaviour 
have looked at the behaviour of the whole herd, likely masking behavioural differences that may have been present between parity groups [5,44].

\section{Conclusions}

This study highlights the complex nature of animal feeding behaviour decisions and the multiple factors influencing this activity. In the present study all animals irrespective of parity or treatment group displayed diurnal grazing and ruminating patterns. The lack of a grazing peak when fresh pasture was allocated in the $36 \mathrm{~h}$ treatment and the more even distribution of grazing activity throughout a $24 \mathrm{~h}$ period highlights the animals inability to anticipate delivery of fresh pasture. Grazing and ruminating time was greatest for primiparous animals in the $12 \mathrm{~h}$ PAF, resulting in greater overall energy expenditure on feeding behaviour. This is due to the lower ranking of primiparous animals within a herd and the greater competition for resources in the $12 \mathrm{~h}$ PAF relative to the $24 \mathrm{~h}$ and $36 \mathrm{~h}$. The results show that management strategies can have a significant effect on animal feeding behaviour but further exploration is required to develop optimum strategies to manage the complex interactions present within a grazing herd to facilitate individual animals to express optimal feeding behaviour and ultimately animal performance.

Author Contributions: Conceptualization, J.G.P., D.A.M. and A.W.G.; methodology, J.G.P., D.A.M. and A.W.G.; formal analysis, A.W.G. and J.G.P.; investigation, J.G.P.; data curation, J.G.P.; supervision, D.A.M.; writing—original draft preparation, J.G.P.; writing—review and editing, J.G.P., D.A.M. and K.M.H. All authors have read and agreed to the published version of the manuscript.

Funding: This research was funded by AgriSearchNI grant number D-88-16. The APC was funded by the Agri-Food and Biosciences Institute.

Institutional Review Board Statement: The study was conducted under an experimental license granted by the Department of Health, Social Services and Public Safety for Northern Ireland in accordance with the Animals Scientific Procedures Act 1986. The study was approved by the Institutional Animal Welfare and Ethical Review Board of the Agri-Food and Biosciences Institute, license code 2754 with studies conducted under the internal project ID D141.

Data Availability Statement: The data presented in this study is available on reasonable request from the corresponding author.

Acknowledgments: The authors thank farm and laboratory staff at the Agri-Food and Biosciences Institute (AFBI) Hillsborough for their assistance with cow management, sampling and chemical analysis of feed samples.

Conflicts of Interest: The authors declare no conflict of interest.

\section{References}

1. Kolver, E.; Muller, L. Performance and nutrient intake of high producing Holstein cows consuming pasture or a total mixed ration. J. Dairy Sci. 1998, 81, 1403-1411. [CrossRef]

2. Rutter, S.; Orr, R.; Yarrow, N.; Champion, R. Dietary preference of dairy cows grazing ryegrass and white clover. J. Dairy Sci. 2004, 87, 1317-1324. [CrossRef]

3. Prendiville, R.; Lewis, E.; Pierce, K.; Buckley, F. Comparative grazing behavior of lactating Holstein-Friesian, Jersey, and Jersey $\times$ Holstein-Friesian dairy cows and its association with intake capacity and production efficiency. J. Dairy Sci. 2010, 93, 764-774. [CrossRef]

4. McEvoy, M.; Kennedy, E.; Murphy, J.; Boland, T.; Delaby, L.; O'donovan, M. The effect of herbage allowance and concentrate supplementation on milk production performance and dry matter intake of spring-calving dairy cows in early lactation. J. Dairy Sci. 2008, 91, 1258-1269. [CrossRef]

5. Abrahamse, P.; Dijkstra, J.; Vlaeminck, B.; Tamminga, S. Frequent allocation of rotationally grazed dairy cows changes grazing behavior and improves productivity. J. Dairy Sci. 2008, 91, 2033-2045. [CrossRef]

6. Vance, E.; Ferris, C.; Elliott, C.; Kilpatrick, D. A comparison of the feeding and grazing behaviour of primiparous Holstein-Friesian and Jersey $\times$ Holstein-Friesian dairy cows. Ir. J. Agric. Food Res. 2012, 51, 45-61.

7. Susenbeth, A.; Mayer, R.; Koehler, B.; Neumann, O. Energy requirement for eating in cattle. J. Anim. Sci. 1998, 76, 2701-2705. [CrossRef] [PubMed]

8. Osuji, P. The physiology of eating and the energy expenditure of the $\mathrm{r}$ uminant at pasture. Rangel. Ecol. Manag. J. Range Manag. Arch. 1974, 27, 437-443. 
9. Dohme-Meier, F.; Kaufmann, L.; Görs, S.; Junghans, P.; Metges, C.; Van Dorland, H.; Bruckmaier, R.; Münger, A. Comparison of energy expenditure, eating pattern and physical activity of grazing and zero-grazing dairy cows at different time points during lactation. Livest. Sci. 2014, 162, 86-96. [CrossRef]

10. Mota-Rojas, D.; Braghieri, A.; Álvarez-Macías, A.; Serrapica, F.; Ramírez-Bribiesca, E.; Cruz-Monterrosa, R.; Masucci, F.; Mora-Medina, P.; Napolitano, F. The use of draught animals in rural labour. Animals 2021, 11, 2683. [CrossRef]

11. Phillips, C.; Rind, M. The effects of social dominance on the production and behavior of grazing dairy cows offered forage supplements. J. Dairy Sci. 2002, 85, 51-59. [CrossRef]

12. Hussein, A.N.; Al-Marashdeh, O.; Bryant, R.H.; Edwards, G. Relationship between Social Dominance and Milk Production of Dairy Cows Grazing Pasture; New Zealand Society of Animal Production: Wellington, New Zealand, 2016.

13. DeVries, T.; Von Keyserlingk, M.; Weary, D. Effect of feeding space on the inter-cow distance, aggression, and feeding behavior of free-stall housed lactating dairy cows. J. Dairy Sci. 2004, 87, 1432-1438. [CrossRef]

14. Chilibroste, P.; Mattiauda, D.; Bentancur, O.; Soca, P.; Meikle, A. Effect of herbage allowance on grazing behavior and productive performance of early lactation primiparous Holstein cows. Anim. Feed Sci. Technol. 2012, 173, 201-209. [CrossRef]

15. Dale, A.; Laidlaw, A.; McGettrick, S.; Gordon, A.; Ferris, C. The effect of grazing intensity on the performance of high-yielding dairy cows. Grass Forage Sci. 2018, 73, 798-810. [CrossRef]

16. Chilibroste, P.; Tamminga, S.; Boer, H. Effects of length of grazing session, rumen fill and starvation time before grazing on dry-matter intake, ingestive behaviour and dry-matter rumen pool sizes of grazing lactating dairy cows. Grass Forage Sci. 1997, 52, 249-257. [CrossRef]

17. DeVries, T.; Von Keyserlingk, M.; Beauchemin, K. Frequency of feed delivery affects the behavior of lactating dairy cows J. Dairy Sci. 2005, 88, 3553-3562. [CrossRef]

18. Schütz, K.; Davison, D.; Matthews, L. Do different levels of moderate feed deprivation in dairy cows affect feeding motivation? Appl. Anim. Behav. Sci. 2006, 101, 253-263. [CrossRef]

19. Verdon, M.; Rawnsley, R.; Raedts, P.; Freeman, M. The behaviour and productivity of mid-lactation dairy cows provided daily pasture allowance over 2 or 7 intensively grazed strips. Animals 2018, 8, 115. [CrossRef]

20. Pollock, J.G.; Gordon, A.W.; Huson, K.M.; McConnell, D.A. The Effect of Frequency of Fresh Pasture Allocation on Pasture Utilisation and the Performance of High Yielding Dairy Cows. Animals 2020, 10, 2176. [CrossRef]

21. Werner, J.; Leso, L.; Umstatter, C.; Niederhauser, J.; Kennedy, E.; Geoghegan, A.; Shalloo, L.; Schick, M.; O’Brien, B. Evaluation of the RumiWatchSystem for measuring grazing behaviour of cows. J. Neurosci. Methods 2018, 300, 138-146. [CrossRef]

22. Werner, J.; Umstatter, C.; Kennedy, E.; Grant, J.; Leso, L.; Geoghegan, A.; Shalloo, L.; Schick, M.; O’Brien, B. Identification of possible cow grazing behaviour indicators for restricted grass availability in a pasture-based spring calving dairy system. Livest. Sci. 2019, 220, 74-82. [CrossRef]

23. Rind, M.; Phillips, C. The effects of group size on the ingestive and social behaviour of grazing dairy cows. Anim. Sci. 1999, 68, 589-596. [CrossRef]

24. Bargo, F.; Muller, L.D.; Delahoy, J.; Cassidy, T. Milk response to concentrate supplementation of high producing dairy cows grazing at two pasture allowances. J. Dairy Sci. 2002, 85, 1777-1792. [CrossRef]

25. Stobbs, T. Automatic measurement of grazing time by dairy cows on tropical grass and legume pastures. Trop. Grassl. 1970, 4 , 237-244.

26. Stockdale, C.; King, K. Effect of stocking rate on the grazing behaviour and faecal output of lactating dairy cows. Grass Forage Sci. 1983, 38, 215-218. [CrossRef]

27. Linnane, M.; Brereton, A.; Giller, P. Seasonal changes in circadian grazing patterns of Kerry cows (Bos taurus) in semi-feral conditions in Killarney National Park, Co. Kerry, Ireland. Appl. Anim. Behav. Sci. 2001, 71, 277-292. [CrossRef]

28. Schirmann, K.; Chapinal, N.; Weary, D.M.; Heuwieser, W.; Von Keyserlingk, M.A. Rumination and its relationship to feeding and lying behavior in Holstein dairy cows. J. Dairy Sci. 2012, 95, 3212-3217. [CrossRef]

29. Gregorini, P.; DelaRue, B.; McLeod, K.; Clark, C.; Glassey, C.; Jago, J. Rumination behavior of grazing dairy cows in response to restricted time at pasture. Livest. Sci. 2012, 146, 95-98. [CrossRef]

30. Vibart, R.; Tavendale, M.; Otter, D.; Schwendel, B.; Lowe, K.; Gregorini, P.; Pacheco, D. Milk production and composition, nitrogen utilization, and grazing behavior of late-lactation dairy cows as affected by time of allocation of a fresh strip of pasture J. Dairy Sci. 2017, 100, 5305-5318. [CrossRef]

31. Dalley, D.; Roche, J.; Moate, P.; Grainger, C. More frequent allocation of herbage does not improve the milk production of dairy cows in early lactation. Aust. J. Exp. Agric. 2001, 41, 593-599. [CrossRef]

32. DeVries, T.; Von Keyserlingk, M.; Beauchemin, K. Diurnal feeding pattern of lactating dairy cows. J. Dairy Sci. 2003, 86, 4079-4082. [CrossRef]

33. Orr, R.; Penning, P.; Harvey, A.; Champion, R. Diurnal patterns of intake rate by sheep grazing monocultures of ryegrass or white clover. Appl. Anim. Behav. Sci. 1997, 52, 65-77. [CrossRef]

34. Gregorini, P.; Eirin, M.; Refi, R.; Ursino, M.; Ansin, O.; Gunter, S. Timing of herbage allocation in strip grazing: Effects on grazing pattern and performance of beef heifers. J. Anim. Sci. 2006, 84, 1943-1950. [CrossRef]

35. Orr, R.; Rutter, S.; Penning, P.; Rook, A. Matching grass supply to grazing patterns for dairy cows. Grass Forage Sci. 2001, 56, 352-361. [CrossRef] 
36. Gregorini, P.; Soder, K.; Sanderson, M.; Ziegler, G.R. Toughness, particle size and chemical composition of meadow fescue (Festuca pratensis Hud.) herbage as affected by time of day. Anim. Feed Sci. Technol. 2009, 151, 330-336. [CrossRef]

37. Phillips, C.; Rind, M. The effects of frequency of feeding a total mixed ration on the production and behavior of dairy cows. J. Dairy Sci. 2001, 84, 1979-1987. [CrossRef]

38. Phillips, C.; Leaver, J. The effect of forage supplementation on the behaviour of grazing dairy cows. Appl. Anim. Behav. Sci. 1986, 16, 233-247. [CrossRef]

39. Niu, M.; Ying, Y.; Bartell, P.; Harvatine, K. The effects of feeding time on milk production, total-tract digestibility, and daily rhythms of feeding behavior and plasma metabolites and hormones in dairy cows. J. Dairy Sci. 2014, 97, 7764-7776. [CrossRef]

40. Atkins, N.E.; Cianchi, C.; Rutter, S.; Williams, S.J.; Gauld, C.; Charlton, G.L.; Sinclair, L.A. Performance, milk fatty acid composition and behaviour of high-yielding Holstein dairy cows given a limited grazing period. Grass Forage Sci. 2020, 75, 181-191. [CrossRef]

41. Bach, A.; Iglesias, C.; Devant, M.; Ràfols, N. Performance and feeding behavior of primiparous cows loose housed alone or together with multiparous cows. J. Dairy Sci. 2006, 89, 337-342. [CrossRef]

42. Wales, W.; Doyle, P.; Dellow, D. Dry matter intake and nutrient selection by lactating cows grazing irrigated pastures at different pasture allowances in summer and autumn. Aust. J. Exp. Agric. 1998, 38, 451-460. [CrossRef]

43. Kondo, S.; Sekine, J.; Okubo, M.; Asahida, Y. The effect of group size and space allowance on the agonistic and spacing behavior of cattle. Appl. Anim. Behav. Sci. 1989, 24, 127-135. [CrossRef]

44. Kennedy, E.; McEvoy, M.; Murphy, J.; O'donovan, M. Effect of restricted access time to pasture on dairy cow milk production, grazing behavior, and dry matter intake. J. Dairy Sci. 2009, 92, 168-176. [CrossRef]

45. Olofsson, J. Competition for total mixed diets fed for ad libitum intake using one or four cows per feeding station. J. Dairy Sci. 1999, 82, 69-79. [CrossRef]

46. Grant, R.; Colenbrander, V.; Albright, J. Effect of particle size of forage and rumen cannulation upon chewing activity and laterality in dairy cows. J. Dairy Sci. 1990, 73, 3158-3164. [CrossRef]

47. Dado, R.; Allen, M. Variation in and relationships among feeding, chewing, and drinking variables for lactating dairy cows. J. Dairy Sci. 1994, 77, 132-144. [CrossRef] 